\title{
Systematic Review and Meta-Analysis of the Prognostic Significance of Neutrophil-Lymphocyte Ratio (NLR) After RO Gastrectomy for Cancer
}

\author{
Katie L Mellor ${ }^{1} \cdot$ Arfon G. M. T. Powell ${ }^{1,2}$ (D) Wyn G. Lewis ${ }^{1}$
}

Published online: 13 June 2018

(C) The Author(s) 2018

\begin{abstract}
Purpose A meta-analysis was performed to evaluate the prognostic value of neutrophil-lymphocyte ratio (NLR) in patients undergoing potentially curative gastrectomy for cancer (GC).

Methods Thomson Reuters Web of Science, Ovid MEDLINE(R) and PUBMED databases were searched for relevant articles using search terms neutrophil-lymphocyte ratio (NLR), GC and survival. Articles reporting overall survival (OS), cancer-specific survival and disease-free survival (DFS), in patients undergoing R0 gastrectomy, were studied.

Results Articles numbering 365 were identified during the preliminary search, and 10 containing 4164 patients were included in the final review. Most patients were $>60$ years of age, male (67\%) and 2239 (53.8\%) had pT3 disease. The number of NLR dichotomization thresholds reported numbered 7, with 2.00 and $3.00(n=2)$ the most common. NLR was associated with poor survival in eight studies with hazard ratios ranging from 1.54 (95\% confidence interval (CI) 1.26-1.89) to 2.99 (1.99-4.49). Pooled odds ratio (OR) for OS was $2.31(1.40-3.83, p=0.001)$ and for DFS $2.72(1.14-6.54, p=0.020)$. Four studies presented T-stage data, OR $1.62(1.33-1.96, p<0.001)$.

Conclusion NLR is an important prognostic indicator associated with both OS and DFS after R0 resection of GC, but the critical level is equivocal.
\end{abstract}

Keywords Gastric cancer $\cdot$ NLR $\cdot$ Neutrophil lymphocyte ratio $\cdot$ Prognosis $\cdot$ Survival

\section{Introduction}

Going by the numbers, gastric cancer (GC) is the fifth most common worldwide cancer diagnosis, and third commonest cause of cancer-related death, accounting for some one million $(951,000)$ new annual diagnoses and 723,000 deaths. [1] Despite earlier diagnosis and improved treatment, nearly one-third of patients undergoing

Katie L Mellor and Arfon G. M. T. Powell contributed equally to this work.

Arfon G. M. T. Powell

powella16@cardiff.ac.uk

1 Wales Post Graduate Medical and Dental Education Deanery School of Surgery, Cardiff University, Cardiff CF14 4XW, UK

2 Division of Cancer and Genetics, Cardiff University, University Hospital of Wales, Heath Park, Cardiff, UK potentially curative surgery experience disease recurrence $[2,3]$ and new prognostic biomarkers would therefore be very welcome.

The systemic inflammatory response (SIR) is a complex bio-system comprising humoral and cellular components that protect the host from harmful pathogens, and a range of SIR biomarkers has been reported to be associated with poor outcomes in gastric cancer. [2, 4] One such biomarker is the neutrophil to lymphocyte ratio (NLR), based on measurement of the hosts' circulating immune cells. Reports have associated the NLR with poor outcome; however, studies were not exclusive to patients undergoing potentially curative resection and the value of NLR in this patient cohort is unclear. Moreover, NLR's value in guiding the use of adjuvant treatment following potentially curative surgery is uncertain. This systematic review and meta-analysis were therefore performed to estimate the prognostic value of NLR in patients undergoing potentially curative gastrectomy and to identify any correlation with histo-pathological T-stage. 


\section{Methods}

\section{Search Protocol}

The outcome measures chosen were overall (OS) and diseasefree survival (DFS). Thomson Reuters Web of Science, Ovid $\operatorname{MEDLINE}(\mathrm{R})$ and PUBMED databases were searched for relevant articles published between 1990 and October 2017. The following search terms were used: (neutrophil lymphocyte ratio OR neutrophil-lymphocyte ratio OR neutrophillymphocyte OR neutrophil-lymphocyte-ratio OR NLR) AND (gastr* OR gastric OR stomach) AND (carcinoma OR adenocarcinoma OR malig* OR malignancy OR tumour OR tumor OR neoplasms).

\section{Study selection (inclusion and exclusion criteria)}

All original scientific articles were considered for inclusion. Reviews and book chapters were excluded, as were texts written in languages other than English. Reports including survival analysis of patients who did not undergo surgery with curative intent were excluded. Only studies related to the association between NLR and survival in patients undergoing potentially curative resection for gastric cancer were included in the systematic review. Only studies reporting extractable data related to OS or DFS were included in the meta-analysis.

\section{Data Extraction}

Two independent reviewers applied the inclusion criteria to study abstracts and selected full papers for data analysis. Fulltext manuscript data was obtained by author (KM), and $50 \%$ of articles underwent independent review (AP), with discrepancies verified by consensus. For each study, baseline data (author, year of publication, country, study period, total number of patients, gender, pTNM stage, neoadjuvant chemotherapy, adjuvant chemotherapy and NLR categorisation thresholds) were recorded. Outcomes were described as odds ratios (OR) with 95\% confidence intervals. Where these were not reported, the methods described by Parmar and Rogers were used to extract data from Kaplan-Meier curves, or percentage survival. [5, 6]
Fig. 1 Flowchart of literature selection

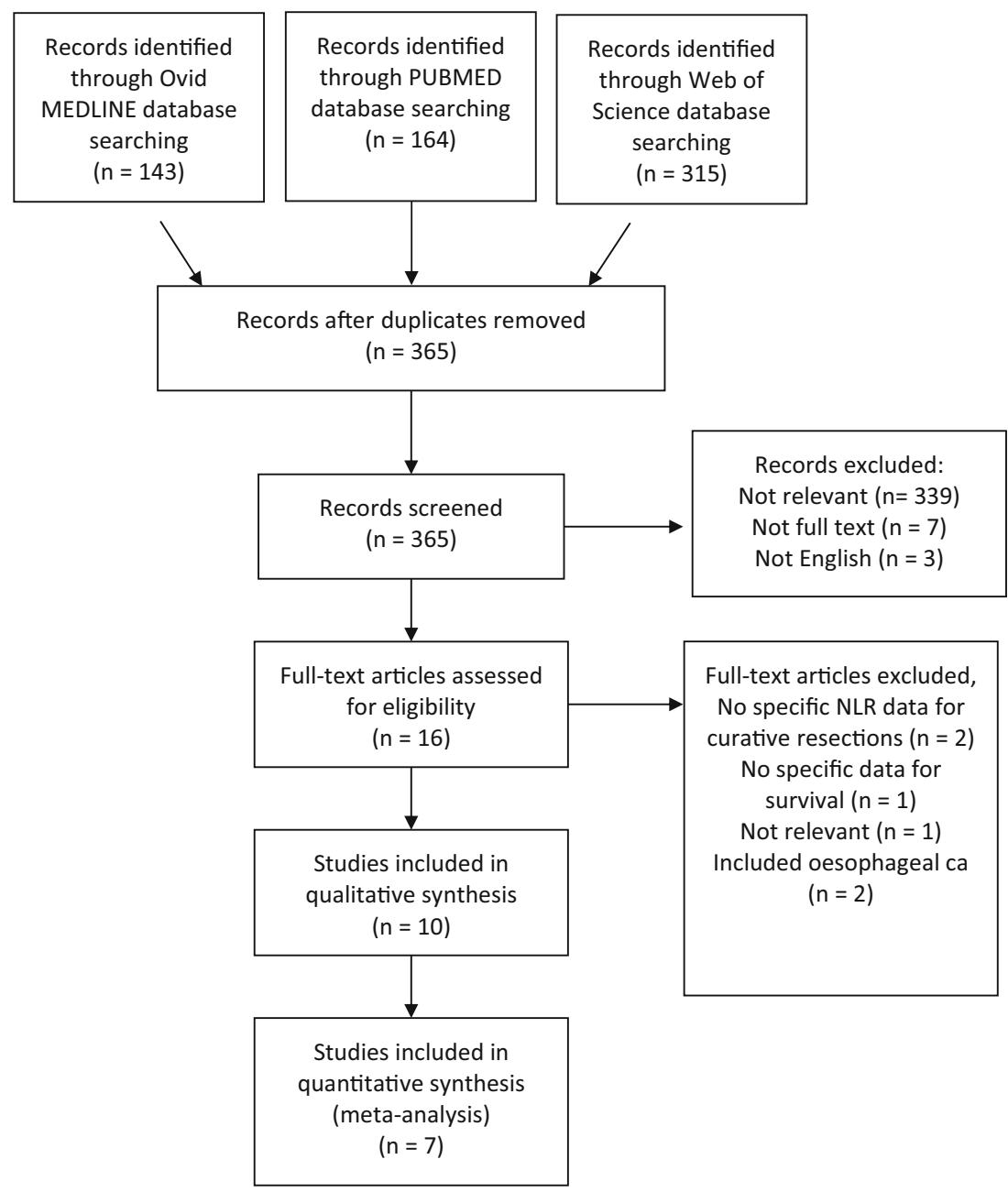


Table 1 Baseline data on included studies

\begin{tabular}{|c|c|c|c|c|c|c|c|c|c|c|c|}
\hline Author & Year & Country & $\begin{array}{l}\text { Study } \\
\text { period }\end{array}$ & $\begin{array}{l}\text { No. of } \\
\text { patients }\end{array}$ & $\begin{array}{l}\text { Age } \\
\text { (years) }\end{array}$ & $\begin{array}{l}\mathrm{M} / \mathrm{F} \\
\text { ratio }\end{array}$ & $\begin{array}{l}\text { AJCC TNM } \\
\text { stage }\end{array}$ & Chemotherapy & Study design & $\begin{array}{l}\text { Evidence } \\
\text { level }\end{array}$ & $\begin{array}{l}\mathrm{N}-\mathrm{O} \\
\text { score }\end{array}$ \\
\hline Dutta & 2012 & UK & 1996-2009 & 120 & $\begin{array}{l}\text { Median } \\
>65\end{array}$ & $1.9: 1$ & $\begin{array}{l}\mathrm{I}=56(47 \%) \\
\mathrm{II}=27(23 \%) \\
\mathrm{III}=37(31 \%)\end{array}$ & $\begin{array}{l}\mathrm{NA}-38.3 \% \\
\mathrm{~A}-\text { not stated }\end{array}$ & Retrospective & IV & 7 \\
\hline Fang & 2017 & China & 2006-2010 & 190 & $\begin{array}{l}\text { Median } \\
>60\end{array}$ & $2.6: 1$ & $\begin{array}{l}\mathrm{II}=65(34 \%) \\
\mathrm{III}=63(33 \%) \\
\mathrm{IV}=62(33 \%)\end{array}$ & $\begin{array}{l}\mathrm{NA} \text { - excluded } \\
\mathrm{A}-\text { not stated }\end{array}$ & Retrospective & IV & 7 \\
\hline Jiang & 2014 & China & 2005-2007 & 377 & $\begin{array}{l}\text { Median } \\
64\end{array}$ & $2.0: 1$ & $\begin{array}{l}\mathrm{I}=37(10 \%) \\
\mathrm{II}=99(26 \%) \\
\mathrm{III}=241(64 \%)\end{array}$ & $\begin{array}{l}\mathrm{NA}-\text { excluded } \\
\mathrm{A}-58.1 \%\end{array}$ & Retrospective & IV & 8 \\
\hline Jung & 2011 & Korea & 2004-2007 & $232^{\mathrm{a}}$ & $\begin{array}{l}\text { Median } \\
63\end{array}$ & Not stated & $\begin{array}{l}\mathrm{III}=138(59 \%) \\
\mathrm{IV}=94(32 \%)\end{array}$ & $\begin{array}{l}\mathrm{NA} \text { - excluded } \\
\mathrm{A}-\text { not stated }\end{array}$ & Retrospective & IV & 7 \\
\hline Lieto & 2017 & Italy & 2000-2015 & $297^{\mathrm{a}}$ & Not stated & $1.4: 1$ & $\begin{array}{l}\mathrm{I}=107(36 \%) \\
\mathrm{II}=122(41 \%) \\
\mathrm{III}=66(22 \%) \\
\mathrm{IV}=2(0 \%)\end{array}$ & $\begin{array}{l}\mathrm{NA}-9.1 \% \\
\mathrm{~A}-63.6 \%\end{array}$ & Retrospective & IV & 8 \\
\hline Liu & 2017 & China & 2000-2012 & 1056 & $\begin{array}{l}\text { Mean } \\
58\end{array}$ & $2.1: 1$ & $\begin{array}{l}\mathrm{I}=194(18 \%) \\
\mathrm{II}=266(25 \%) \\
\mathrm{III}=596(56 \%)\end{array}$ & $\begin{array}{l}\mathrm{NA} \text { - excluded } \\
\mathrm{A} \text { - suitable stage II-III }\end{array}$ & Retrospective & IV & 7 \\
\hline Mohri & 2016 & Japan & 2000-2011 & 404 & $\begin{array}{l}\text { Median } \\
67\end{array}$ & $2.3: 1$ & $\begin{array}{l}\mathrm{I}=260(64 \%) \\
\mathrm{II}=70(17 \%) \\
\mathrm{III}=74(18 \%)\end{array}$ & $\begin{array}{l}\mathrm{NA} \text {-not stated } \\
\mathrm{A}-\text { not stated }\end{array}$ & Retrospective & IV & 7 \\
\hline Powell & 2017 & U.K. & 2004-2016 & 291 & Median 69 & $2.0: 1$ & $\begin{array}{l}\mathrm{I}=79(27 \%) \\
\mathrm{II}=92(32 \%) \\
\mathrm{III}=120(41 \%)\end{array}$ & $\begin{array}{l}\mathrm{NA}-15.5 \% \\
\mathrm{~A}-21.0 \%\end{array}$ & Retrospective & IV & 7 \\
\hline Sun & 2016 & China & 2000-2012 & 873 & $\begin{array}{l}\text { Median } \\
59\end{array}$ & $2.1: 1$ & $\begin{array}{l}\mathrm{I}=108(12 \%) \\
\mathrm{II}=185(21 \%) \\
\mathrm{III}=580(66 \%)\end{array}$ & $\begin{array}{l}\text { NA-excluded } \\
\mathrm{A}-66.7 \%\end{array}$ & Retrospective & IV & 7 \\
\hline Wang & 2011 & China & 2006-2009 & 324 & Not stated & $2.3: 1$ & $\mathrm{III}=324(100 \%)$ & $\begin{array}{l}\text { NA-excluded } \\
\mathrm{A}-64.8 \%\end{array}$ & Retrospective & IV & 7 \\
\hline
\end{tabular}

${ }^{\text {a }}$ Only data for curative resections extracted

$N A$ neoadjuvant, $A$ adjuvant, $N-O$ Newcastle-Ottawa

\section{Quality Analysis}

This meta-analysis was conducted in accordance with the preferred reporting items for systematic reviews and metaanalyses (PRISMA) guidelines. [7] The quality of the studies was measured using the Newcastle-Ottawa scale, assessing the methodological quality of non-randomised cohort studies for meta-analyses. Studies were judged by two independent assessors, using a nine-point scale comprising analysis on the selection of the study group, the comparability of cohorts and the ascertainment of outcome. Scores above 6 points were taken to denote studies of high methodological quality and were included in the meta-analysis. Studies were excluded if methodological quality was poor (Newcastle-Ottawa scores $<7$ ). [8]

\section{Statistical Analysis}

Statistical analyses were performed using RevMan statistical package (Review Manager (RevMan) Version 5.3. Copenhagen: The Nordic Cochrane Centre, The Cochrane
Collaboration, 2014). Heterogeneity between studies was measured by calculating the $I^{2}$ statistic that was calculated for an objective measure of heterogeneity. A fixed-effect meta-analysis was performed in all cases, and where there was appreciable heterogeneity $\left(I^{2}>50 \%\right.$ or Chi-squared $p$ value $<$ 0.10 ), a random-effect model was used. Corresponding funnel plots of Ln standard error as a function of effect size were used to examine the effect of publication bias visually and were statistically tested using Eggers test; $p$ values $>0.05$ were taken as indicative of no publication bias. For meta-analysis, absolute numbers of deaths, recurrences and pT-stages in the high and low NLR cohorts were extracted.

\section{Results}

The initial electronic search yielded 365 studies, of which 349 were excluded based on abstract content (Fig. 1). Three hundred and thirty-nine were not relevant, seven were not available as full texts, and three were not English language manuscripts. Of the 16 full text manuscripts evaluated, two did not 
Table 2 Baseline data on included studies

\begin{tabular}{|c|c|c|c|c|c|c|c|}
\hline Author & Year & $\begin{array}{l}\text { Outcome } \\
\text { measure }\end{array}$ & NLR cut-off & $\begin{array}{l}\text { 5-year } \\
\text { survival }\end{array}$ & $\begin{array}{l}\text { Justification of } \\
\text { cut-off value }\end{array}$ & $\begin{array}{l}\text { Hazard ratio } \\
\text { (confidence } \\
\text { interval) }\end{array}$ & Association with survival \\
\hline Dutta & 2012 & CSS & $\begin{array}{l}<2.5-\text { low } \\
2.5-5- \\
\quad \text { intermediate } \\
>5 \text { - high }\end{array}$ & N/A & Not stated & $1.19(0.76-1.87)$ & No association $(p=0.454)$ \\
\hline Fang $^{9}$ & 2017 & OS & $\begin{array}{l}<2 \text { - low } \\
\geq 2 \text { - high }\end{array}$ & $\begin{array}{l}89.5 \% \\
76.9 \%\end{array}$ & Median values & $2.32(1.08-5.02)$ & $\begin{array}{l}\text { High NLR, poorer survival } \\
\qquad(p=0.032)\end{array}$ \\
\hline Jiang & 2014 & OS & $\begin{array}{l}<1.44 \text { - low } \\
\geq 1.44 \text {-high }\end{array}$ & $\begin{array}{l}63.2 \% \\
36.6 \%\end{array}$ & ROC curve analysis & $1.60(1.05-2.44)$ & $\begin{array}{l}\text { High NLR, poorer survival } \\
\qquad(p=0.030)\end{array}$ \\
\hline Jung & 2011 & DFS & $\begin{array}{l}<3 \text { - low } \\
\geq 3 \text { - high }\end{array}$ & $\begin{array}{l}44.1 \% \\
13.0 \%\end{array}$ & Quartiles & $1.65(1.09-2.52)$ & $\begin{array}{l}\text { High NLR, poorer survival } \\
\qquad(p=0.019)\end{array}$ \\
\hline Lieto & 2017 & DFS & $\begin{array}{l}\leq 3.22 \text { - low } \\
>3.22 \text { - high }\end{array}$ & $\begin{array}{l}72.6 \% \\
30.5 \%\end{array}$ & $\begin{array}{l}\text { Maximum log rank } \\
\text { statistics }\end{array}$ & $2.99(1.99-4.49)$ & $\begin{array}{l}\text { High NLR, poorer survival } \\
\qquad(p<0.001)\end{array}$ \\
\hline Liu & 2017 & OS & $\begin{array}{l}<2-\text { low } \\
\geq 2 \text { - high }\end{array}$ & $\begin{array}{l}62.0 \% \\
47.0 \%\end{array}$ & Previous study & $1.54(1.26-1.89)$ & $\begin{array}{l}\text { High NLR, poorer survival } \\
\qquad(p<0.001)\end{array}$ \\
\hline Mohri & 2016 & OS & $\begin{array}{l}\leq 3-\text { low } \\
>3-\text { high }\end{array}$ & N/A & ROC curve analysis & $2.91(1.71-4.94)$ & $\begin{array}{l}\text { High NLR, poorer survival } \\
\qquad(p<0.001)\end{array}$ \\
\hline Powell & 2017 & $\begin{array}{l}\text { DFS and } \\
\text { OS }\end{array}$ & $\begin{array}{l}\leq 5.5 \text {-low } \\
>5.5 \text { - high }\end{array}$ & $\begin{array}{l}70.7 \%^{\mathrm{a}} \\
59.1 \%\end{array}$ & Previous study & $\begin{array}{l}{ }^{\mathrm{a}} 1.43(0.78-2.65) \\
\mathrm{b} 1.01(0.58-1.76)\end{array}$ & $\begin{array}{l}\text { NLR not associated with survival } \\
\quad\left(p=0.249^{\mathrm{a}} \text { and } p=0.975^{\mathrm{b}}\right)\end{array}$ \\
\hline Sun & 2016 & OS & $\begin{array}{l}<2.3 \text {-low } \\
\geq 2.3 \text { - high }\end{array}$ & $\begin{array}{l}85.1 \% \\
57.0 \%\end{array}$ & ROC curve analysis & $1.66(1.39-1.99)$ & $\begin{array}{l}\text { High NLR, poorer survival } \\
\qquad(p=0.001)\end{array}$ \\
\hline Wang & 2011 & OS & $\begin{array}{l}\leq 5-\text { low } \\
>5 \text { - high }\end{array}$ & N/A & Previous study & $2.47(1.21-5.05)$ & $\begin{array}{l}\text { High NLR, poorer survival } \\
\qquad(p=0.013)\end{array}$ \\
\hline
\end{tabular}

CSS cancer-specific survival, DFS disease-free survival, $O S$ overall survival, $N / A$ not available

${ }^{\mathrm{a}}$ Data for DFS

${ }^{\mathrm{b}}$ Data for OS

include specific data for curative resections, one did not report survival data, one was not relevant to the study topic and two included data related to oesophageal cancer. Consequently, ten studies were included for qualitative analysis (Table 1) [2, 9-17]. The median Newcastle-Ottawa quality score for these studies was seven (range 7-8). All studies were retrospective cohort studies of one or more regional institutions representing level IV evidence.

The ten studies included a total of 4164 patients with a mean sample size of 418 (range 120-1056). The majority of patients were aged 60 years or older, with an age range of 19 to 89 years and were predominantly male (mean M/ F ratio 2.1:1) (Table 1).

Seven studies included patients with pTNM stage I-III disease, and three also including patients with stage IV cancer, all undergoing potentially curative resection (Table 1 ). The majority of study patients had pT3 disease $(n=2239,53.8 \%)$, with fewer patients reported to have locally confined disease $(\mathrm{pT} 1=841,20.2 \%$ and $\mathrm{pT} 2=926,22.2 \%)$ and $3.8 \%$ reported to have pT4 tumours $(n=158)$. Neoadjuvant chemotherapy was given in three of the studies $[2,9,13]$ and postoperative chemotherapy was administered to patients in six

\begin{tabular}{|c|c|c|c|c|c|c|}
\hline \multirow[b]{2}{*}{ Study or Subgroup } & \multicolumn{2}{|c|}{ High NLR } & \multicolumn{2}{|c|}{ Low NLR } & \multirow[b]{2}{*}{ Weight } & Odds Ratio \\
\hline & Events & Total & Events & Total & & M-H, Random, $95 \% \mathrm{CI}$ \\
\hline Fang et al 2017 & 24 & 104 & 9 & 86 & $15.3 \%$ & $2.57[1.12,5.87]$ \\
\hline Jiang et al 2014 & 196 & 309 & 25 & 68 & $20.0 \%$ & $2.98[1.73,5.14]$ \\
\hline Liu et al 2017 & 292 & 551 & 192 & 505 & $24.6 \%$ & $1.84[1.44,2.35]$ \\
\hline Powell et al 2017 & 15 & 30 & 138 & 261 & $16.4 \%$ & $0.89[0.42,1.90]$ \\
\hline Sun et al 2016 & 148 & 344 & 79 & 529 & $23.6 \%$ & $4.30[3.12,5.93]$ \\
\hline Total $(95 \% \mathrm{CI})$ & & 1338 & & 1449 & $100.0 \%$ & $2.31[1.40,3.83]$ \\
\hline Total events & 675 & & 443 & & & \\
\hline $\begin{array}{l}\text { Heterogeneity. Ta } \\
\text { Test for owerall ef }\end{array}$ & $\begin{array}{l}25 ; \mathrm{Cr} \\
3.27\end{array}$ & 0 & 9, df $=$ & & & \\
\hline
\end{tabular}

Fig. 2 Association between high NLR and overall survival (pooled analysis) 


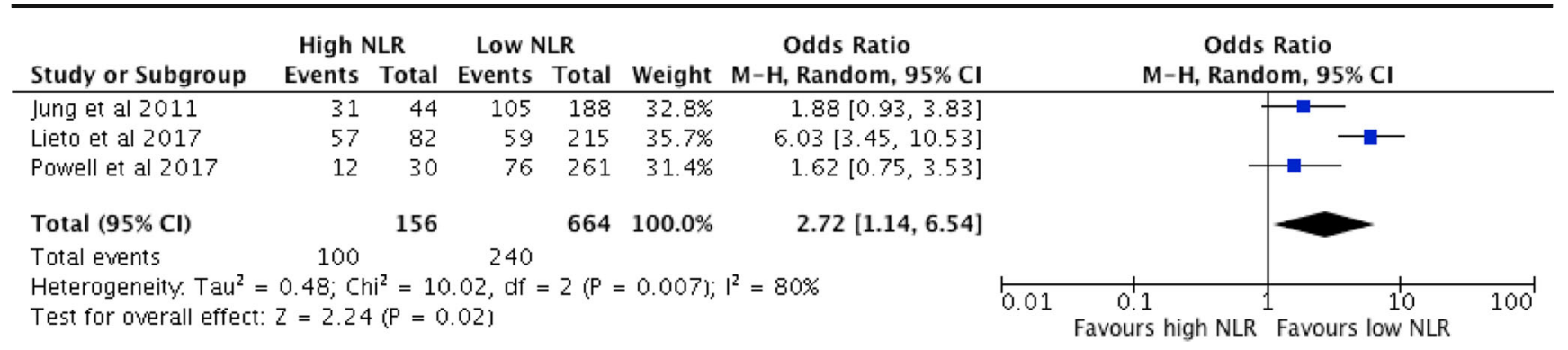

Fig. 3 Association between high NLR and disease-free survival (pooled analysis)

of the studies. $[2,11,13,14,16,17]$ The proportions of patients receiving post-operative chemotherapy ranged from 21.0 to $66.7 \%$.

The NLR critical values reported varied between studies with the commonest value 2.00 and $3.00(n=2)$. Six studies reported an association between high NLR and poor overall survival, $[10,11,14-17]$ two studies reported an association between NLR and disease-free survival [12,13] and one study reported no association with cancer-specific survival [10] (Table 2). Four studies reported an association between NLR and advanced pT-stage. [10, 11, 14, 15]

\section{Relationship Between NLR and Overall Survival}

Five studies reported data related to overall survival in 2787 patients undergoing potentially curative $\mathrm{R} 0$ gastrectomy. The pooled odds ratio was 2.31 (95\% CI 1.40-3.83, $p=0.001)$. Significant study heterogeneity was observed $\left(\chi^{2}=24.49, d f\right.$ $\left.4, p<0.0001, I^{2}=84 \%\right)$. The Forest plot for these results is shown in Fig. 2.

\section{Relationship Between NLR and Disease-Free Survival}

Three studies reported data related to NLR and diseasefree survival, comprising a total of 820 patients undergoing potentially curative gastrectomy. The pooled odds ratio was $2.72(95 \%$ CI $1.14-6.54, p=0.020$, Fig. 3). Once again, significant study heterogeneity was observed $\left(\chi^{2}=\right.$ 10.02, $\left.d f 2, p=0.007, I^{2}=80 \%\right)$.

\section{Relationship Between NLR and pT Stage}

Four studies reported data related to $\mathrm{pT}$ stage comprising a total of 2027 patients. The pooled odds ratio was 1.62 (95\% CI $1.33-1.96, p<0.001$, Fig. 4). No heterogeneity was observed in this cohort $\left(\chi^{2}=5.12\right.$, df $\left.3 p=0.160, I^{2}=41 \%\right)$.

\section{Discussion}

This meta-analysis is the first to examine exclusively the prognostic value of NLR in patients undergoing potentially curative R0 gastrectomy for cancer. The principal findings were that no fewer than $40 \%$ of patients had an elevated preoperative NLR, in keeping with other gastric cancer metaanalyses (range 36.5-59.8\%). [3, 18-20] This patient cohort was over $50 \%$ more likely to have higher pT stage, which was associated with over two-fold risk of disease recurrence, and commensurately poorer long-term cumulative survival. Yet, the threshold for NLR dichotomization varied across eight of the studies analysed, threatening any argument for incorporating NLR into a core prognostic algorithm. But such strong predictive associations suggest that the systemic inflammatory response has the potential to be an important therapeutic biomarker, meriting targeted research.

The NLR has been studied in a variety of solid cancers [21] including breast [22], colorectal [23], esophageal [24], lung [25] and pancreas [26]. Reported pooled hazard ratios for NLR and OS have ranged from 1.40 in oesophageal cancer [24] to 2.61 in pancreatic cancer [26], compared with 2.31 in

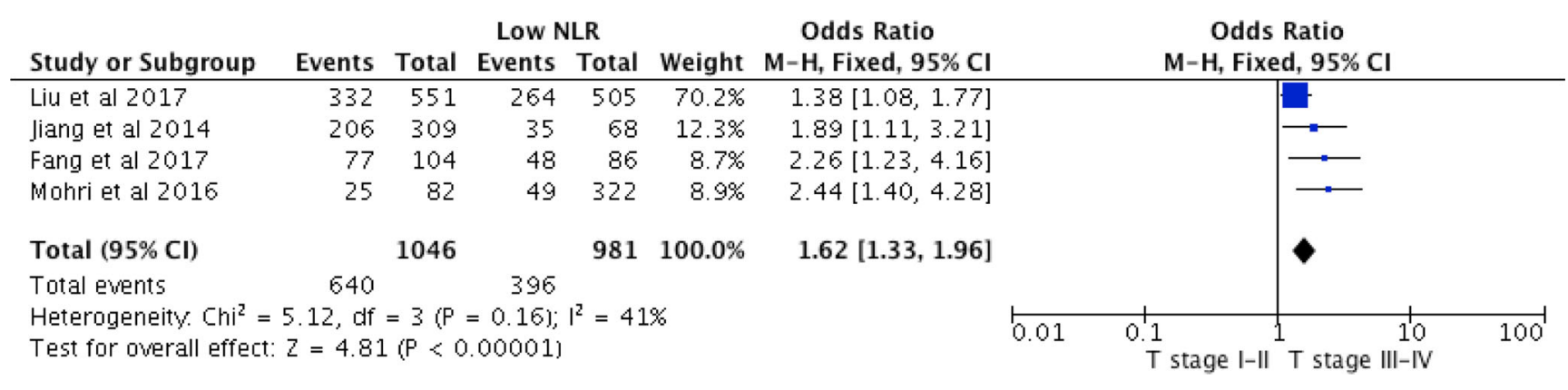

Fig. 4 Association between high NLR and T-stage (pooled analysis) 
this study. The reason for this is unclear, but may reflect the different dichotomization thresholds reported related to the spectrum of cancers studied. Here, 8 of 10 studies used different dichotomization thresholds; similarly, 9 of 11 reported in breast cancer, 4 of 16 in colorectal cancer, 6 of 7 in oesophageal cancer, 10 of 15 in lung cancer and 4 of 11 in pancreatic cancer. This heterogeneity in dichotomization thresholds is a significant limiting factor in comparing findings between cancer types as well as individual articles grouped by anatomical site, and efforts to standardise reporting of NLR methodology are desirable to facilitate comparative research.

NLR is one among a spectrum of seven inflammationbased prognostic biomarkers associated with poor survival in gastric cancer [2], including CRP, albumin, Glasgow prognostic score, platelet-lymphocyte ratio, neutrophil-platelet score and lymphocyte-monocyte ratio. Inflammation has been proven to play an important role in the development and/or progression of several cancers due to carcinogenesis promotion. [27, 28] Moreover, a meta-analysis of 2.3 million individuals reported a $25 \%$ reduction in the risk of gastric cancer associated with NSAID use. [29] Any reasonable observer would surely agree that attenuating the systemic inflammatory response by means of non-steroidal anti-inflammatory drug (NSAID) therapy holds promise. Unfortunately, given the potential adverse side effects associated with routine NSAID use, their indiscriminate peri-operative use would carry a palpable and significant risk. Identifying responders who would benefit the most is therefore an important dilemma to which NLR may hold the key.

This meta-analysis has a number of inherent limitations. Heterogeneity existed between studies, which may be explained by a number of factors, not least the variation in NLR critical values and patient characteristics including disease stage, age and treatment. All studies analysed were retrospective in methodology, and cohort in nature, providing pooled rather than individual patient data. Not all reported extractable data, limiting the number available for analysis. NLR has been described as a possible prognostic marker in other diseases such as the acute coronary syndrome, [30] and as such, the influence of NLR may not necessarily be cancer specific, and attenuating the systemic inflammatory response may promote survival irrespective of the effect of malignancy, which is an arena that requires clarification. In contrast, the study has several strengths. Similar TNM stages and chemotherapy rates to other meta-cohorts strengthen the reliability of the findings. Previous meta-analyses included a heterogeneous mixture of treatment intents, including both potentially curative as well as palliative treatments, and this meta-analysis is the first to exclusively examine NLR's prognostic significance after potentially curative R0 gastrectomy. The clinical challenge is to identify which patients who have undergone potentially curative resection might benefit from adjuvant therapies because of their higher risk of disease recurrence, regardless of pTNM stage.

In conclusion, despite improvements in staging and surgical technique, approximately one third of patients who undergo potentially curative gastrectomy for cancer will suffer disease recurrence. [31]. NLR, derived and calculated from absolute counts of serum lymphocytes and neutrophils, is routinely performed during pre-operative full blood count workup, and is therefore not only readily available but also inexpensive. Incorporating NLR into MDT algorithms to refine and plan treatment strategies and predict prognosis is currently limited by the variety and inconsistencies in reported dichotomization thresholds. Before this can be achieved, an adequately powered study comparing critical dichotomisation or categorisation threshold is needed to identify a pragmatic optimal critical ratio. Finally, further work should focus on establishing the prognostic value of NLR in patients suitable for potentially curative gastric cancer surgery followed by planned adjuvant anti-inflammatory treatment.

Authors' Contribution Katie Mellor - design, data collection, analysis, drafting of manuscript and agreeing on a final draft.

Arfon G M T Powell-conceptualization, design, data collection, analysis, drafting of manuscript and agreeing on a final draft.

Wyn G Lewis - Design, analysis, drafting of manuscript and agreeing on a final draft.

\section{Compliance with Ethical Standards}

Conflict of Interest Katie Mellor declares that she has no conflict of interest. Arfon Powell declares he has no conflict of interest. Wyn Lewis declares he has no conflict of interest.

Ethical Approval This article does not contain any studies with human participants or animals performed by any of the authors.

Open Access This article is distributed under the terms of the Creative Commons Attribution 4.0 International License (http:// creativecommons.org/licenses/by/4.0/), which permits unrestricted use, distribution, and reproduction in any medium, provided you give appropriate credit to the original author(s) and the source, provide a link to the Creative Commons license, and indicate if changes were made.

\section{References}

1. Ferlay J, Soerjomataram I, Dikshit R, Eser S, Mathers C, Rebelo M, et al. Cancer incidence and mortality worldwide: Sources, methods and major patterns in GLOBOCAN 2012. Int J Cancer [Internet]. 2015 [cited 2017 Dec 11];136:E359-86. Available from: http:// www.ncbi.nlm.nih.gov/pubmed/25220842

2. Powell AGMT, Parkinson D, Patel N, Chan D, Christian A, Lewis WG. Prognostic significance of serum inflammatory markers in gastric Cancer. J Gastrointest Surg [Internet]. 2017 [cited 2018 Jan 4]; Available from: https://link.springer.com/content/pdf/10. 1007\%2Fs11605-017-3597-5.pdf

3. Zhang X, Zhang W, Feng L. Prognostic significance of neutrophil lymphocyte ratio in patients with gastric Cancer: a Meta-analysis. Katoh M, editor. PLoS One [Internet]. 2014 [cited 2017 Dec 11];9: 
e111906. Available from: https://doi.org/10.1371/journal.pone. 0111906

4. Zhang X, Zhang W, Feng L. Prognostic significance of neutrophil lymphocyte ratio in patients with gastric Cancer: a Meta-analysis. Katoh M, editor. PLoS One [Internet]. Public Library of Science; 2014 [cited 2017 Dec 11];9:e111906. Available from: https://doi. org/10.1371/journal.pone.0111906

5. Parmar MK, Torri V, Stewart L. Extracting summary statistics to perform meta-analyses of the published literature for survival endpoints. Stat Med [Internet]. 1998 [cited 2017 Dec 11];17:2815-34. Available from: http://www.ncbi.nlm.nih.gov/pubmed/9921604

6. Rogers AC, Winter DC, Heeney A, Gibbons D, Lugli A, Puppa G, Sheahan K Systematic review and meta-analysis of the impact of tumour budding in colorectal cancer. Br J Cancer [Internet]. 2016 [cited 2017 Dec 11];115:831-40. Available from: http://www.ncbi. nlm.nih.gov/pubmed/27599041, 840

7. Moher D, Liberati A, Tetzlaff J, Altman DG, Group TP. Preferred Reporting Items for Systematic Reviews and Meta-Analyses: The PRISMA Statement. PLoS Med [Internet]. Public Library of Science; 2009 [cited 2017 Dec 14];6:e1000097. Available from: doi: https://doi.org/10.1371/journal.pmed.1000097

8. Wells G, Shea B, O'connell D, Peterson J, Welch V, Losos M, et al. The Newcastle-Ottawa Scale (NOS) for assessing the quality of nonrandomised studies in meta- analyses. [cited 2017 Dec 14]; Available from: http://www.medicine.mcgill.ca/rtamblyn/ Readings\%5CThe Newcastle - Scale for assessing the quality of nonrandomised studies in meta-analyses.pdf.

9. Dutta S, Crumley ABC, Fullarton GM, Horgan PG, McMillan DC. Comparison of the prognostic value of tumour and patient related factors in patients undergoing potentially curative resection of gastric cancer. Am J Surg [Internet]. Elsevier Inc.; 2012;204:294-9. Available from: doi:https://doi.org/10.1016/j.amjsurg.2011.10.015

10. Fang Y, Lu J, Liu F. Clinical value of preoperative inflammatory parameters in advanced node-negative Gastric Cancer patients following radical gastrectomy. Int J Clin Exp Med [Internet]. 2017 [cited 2017 Dec 11];10:6780-90. Available from: www.ijcem.com

11. Jiang N, Deng J-Y, Liu Y, Ke B, Liu H-G, Liang H. The role of preoperative neutrophil-lymphocyte and platelet-lymphocyte ratio in patients after radical resection for gastric cancer. Biomarkers [Internet]. 2014 [cited 2017 Dec 11];19:444-51. Available from: http://www.ncbi.nlm.nih.gov/pubmed/24910346, 451

12. Jung MR, Park YK, Jeong O, Seon JW, Ryu SY, Kim DY, et al. Elevated preoperative neutrophil to lymphocyte ratio predicts poor survival following resection in late stage gastric cancer. J Surg Oncol [Internet]. 2011 [cited 2017 Dec 11];104:504-10. Available from: http://www.ncbi.nlm.nih.gov/pubmed/21618251

13. Lieto E, Galizia G, Auricchio A, Cardella F, Mabilia A, Basile N, del Sorbo G, Castellano P, Romano C, Orditura M, Napolitano V Preoperative neutrophil to lymphocyte ratio and lymphocyte to monocyte ratio are prognostic factors in gastric cancers undergoing surgery. J Gastrointest Surg [Internet]. 2017 [cited 2017 Dec 11];21: 1764-74. Available from: http://www.ncbi.nlm.nih.gov/pubmed/ 28752404, 1774

14. Liu X, Chen S, Liu J, Xu D, Li W, Zhan Y, Li Y, Chen Y, Zhou Z, Sun $X$ Impact of systemic inflammation on gastric cancer outcomes. Coleman WB, editor. PLoS One [Internet]. 2017 [cited 2017 Dec 11];12:e0174085. Available from: http://www.ncbi.nlm. nih.gov/pubmed/28358923

15. Mohri Y, Tanaka K, Toiyama Y, Ohi M, Yasuda H, Inoue Y, Kusunoki M Impact of preoperative neutrophil to lymphocyte ratio and postoperative infectious complications on survival after curative gastrectomy for gastric Cancer: a single institutional cohort study. Medicine (Baltimore) [Internet]. Wolters Kluwer Health; 2016 [cited 2017 Dec 11];95:e3125. Available from: http://www. ncbi.nlm.nih.gov/pubmed/26986164
16. Sun $X$, wang juncheng, liu jianjun, chen shangxiang, Liu $X$. Albumin concentrations plus neutrophil lymphocyte ratios for predicting overall survival after curative resection for gastric cancer. Onco Targets Ther [Internet]. 2016 [cited 2017 Dec 11];Volume 9: 4661-9. Available from: http://www.ncbi.nlm.nih.gov/pubmed/ 27536130

17. Wang D, Ren C, Qiu M, Luo H, Wang Z, Zhang D, et al. Comparison of the prognostic value of various preoperative inflammation-based factors in patients with stage III gastric cancer. Tumor Biol [Internet]. 2012 [cited 2017 Dec 11];33:749-56. Available from: http://www.ncbi.nlm.nih.gov/pubmed/22198641

18. Chen J, Hong D, Zhai Y, Shen P. Meta-analysis of associations between neutrophil-to-lymphocyte ratio and prognosis of gastric cancer. World J Surg Oncol [Internet]. BioMed Central; 2015 [cited 2017 Dec 11];13:122. Available from: http://www.ncbi.nlm.nih. gov/pubmed/25889889

19. Sun J, Chen X, Gao P, Song Y, Huang X, Yang Y, et al. Can the Neutrophil to Lymphocyte Ratio Be Used to Determine Gastric Cancer Treatment Outcomes? A Systematic Review and MetaAnalysis. Dis Markers [Internet]. 2016 [cited 2017 Dec 11];2016: 1-10. Available from: http://www.ncbi.nlm.nih.gov/pubmed/ 26924872

20. Xin-Ji Z, Yong-Gang L, Xiao-Jun S, Xiao-Wu C, Dong Z, Da-Jian $Z$. The prognostic role of neutrophils to lymphocytes ratio and platelet count in gastric cancer: A meta-analysis. Int J Surg [Internet]. Elsevier; 2015 [cited 2017 Dec 11];21:84-91. Available from: http://www.ncbi.nlm.nih.gov/pubmed/26225826

21. Templeton AJ, McNamara MG, Šeruga B, Vera-Badillo FE, Aneja $\mathrm{P}$, Ocaña A, et al. Prognostic role of neutrophil-to-lymphocyte ratio in solid tumors: a systematic review and Meta-analysis. JNCI J Natl Cancer Inst [internet]. Oxford University Press; 2014 [cited 2018 Jan 28];106. Available from: https://doi.org/10.1093/jnci/dju124, Prognostic Role of Neutrophil-to-Lymphocyte Ratio in Solid Tumors: A Systematic Review and Meta-Analysis

22. Liu X, Qu J-K, Zhang J, Yan Y, Zhao X-X, Wang J-Z, Qu HY, Liu L, Wang JS, Duan XY Prognostic role of pretreatment neutrophil to lymphocyte ratio in breast cancer patients: a meta-analysis. Medicine (Baltimore) [Internet]. Wolters Kluwer Health; 2017 [cited 2018 Jan 28];96:e8101. Available from: http://www.ncbi.nlm. nih.gov/pubmed/29137007

23. Li M-X, Liu X-M, Zhang X-F, Zhang J-F, Wang W-L, Zhu Y, et al. Prognostic role of neutrophil-to-lymphocyte ratio in colorectal cancer: A systematic review and meta-analysis. Int J Cancer [Internet]. 2014 [cited 2018 Jan 28];134:2403-13. Available from: https://doi. org/10.1002/ijc.28536

24. Yodying H, Matsuda A, Miyashita M, Matsumoto S, Sakurazawa $N$, Yamada M, et al. Prognostic significance of neutrophil-tolymphocyte ratio and platelet-to-lymphocyte ratio in oncologic outcomes of esophageal Cancer: a systematic review and Meta-analysis. Ann Surg Oncol [Internet]. 2015 [cited 2018 Jan 28];23:64654. https://doi.org/10.1245/s10434-015-4869-5

25. Gu X-B, Tian T, Tian X-J, Zhang X-J. Prognostic significance of neutrophil-to-lymphocyte ratio in non-small cell lung cancer: a meta- analysis. Nat Publ Gr [Internet]. 2015 [cited 2018 Jan 28]; Available from: https://www.ncbi.nlm.nih.gov/pmc/articles/ PMC4513342/pdf/srep12493.pdf

26. Yang J-J, Hu Z-G, Shi W-X, Deng T, He S-Q, Yuan S-G. Prognostic significance of neutrophil to lymphocyte ratio in pancreatic cancer: a meta-analysis. World J Gastroenterol [Internet]. Baishideng Publishing Group Inc; 2015 [cited 2018 Jan 28];21:2807-15. Available from: http://www.ncbi.nlm.nih.gov/pubmed/25759553

27. Kubota T, Hiki N, Nunobe S, Kumagai K, Aikou S, Watanabe R, Sano T, Yamaguchi T Significance of the inflammation-based Glasgow prognostic score for short- and long-term outcomes after curative resection of gastric Cancer. J Gastrointest Surg [Internet]. 
2012 [cited 2017 Dec 11];16:2037-44. Available from: http://www. ncbi.nlm.nih.gov/pubmed/23007284, 2044

28. Hanahan D, Weinberg RA. Hallmarks of Cancer: the next generation. Cell [Internet]. 2011 [cited 2017 Dec 11];144:646-74. Available from: http://www.ncbi.nlm.nih.gov/pubmed/ 21376230, 674

29. Kong $\mathrm{P}, \mathrm{Wu} \mathrm{R}$, Liu X, Liu J, Chen S, Ye M, et al. The Effects of Anti-inflammatory Drug Treatment in Gastric Cancer Prevention: an Update of a Meta-analysis. J Cancer [Internet]. Ivyspring International Publisher; 2016 [cited 2017 Dec 11];7:2247-57. Available from: http://www.ncbi. nlm.nih.gov/pubmed/27994661
30. Tamhane UU, Aneja S, Montgomery D, Rogers E-K, Eagle KA, Gurm HS. Association Between Admission Neutrophil to Lymphocyte Ratio and Outcomes in Patients With Acute Coronary Syndrome. Am J Cardiol [Internet]. 2008 [cited 2017 Dec 11];102:653-7. Available from: http://www.ncbi.nlm.nih.gov/ pubmed/18773982

31. Spolverato G, Ejaz A, Kim Y, Squires MH, Poultsides GA, Fields $\mathrm{RC}$, et al. Rates and patterns of recurrence after curative intent resection for gastric cancer: a United States multi-institutional analysis. J Am Coll Surg [Internet]. Elsevier; 2014 [cited 2017 Dec 11];219:664-75. Available from: http://www.ncbi.nlm.nih.gov/ pubmed/25154671 